\title{
SUBCUTANEOUS, GANGLION AND PULMONARY SARCOIDOSIS IN A PATIENT WITH CHRONIC HEPATITIS C VIRUS INFECTION
}

\author{
Nicoleta State ${ }^{1,2}$, Alexandrina Pascal ${ }^{2}$, Karina Bilavscki ${ }^{3}$, Adrian Tataranu² $^{2}$ \\ ${ }^{1}$ University of Medicine and Pharmacy "Carol Davila", Bucharest \\ ${ }^{2}$ County Emergency Hospital "Sf. Ioan cel Nou", Suceava \\ ${ }^{3}$ Regional Institute of Oncology, Iasi \\ Corresponding author: Nicoleta State \\ Spitalul Judetean de Urgenta "Sf. Ioan cel Nou", bd. 1 Decembrie 1918, nr 21 bis, Suceava, \\ judet Suceava, sectia Medicina Interna \\ E-mail: dr.state.nicoleta@gmail.com
}

\begin{abstract}
Chronic hepatitis $C$ and sarcoidosis are both well-known diseases. Some studies support the hypothesis that the hepatitis $C$ virus (HCV) may trigger sarcoidosis ${ }^{(1)}$. We present a case of chronic hepatitis $C$, developing a silent lung systemic disease with subcutaneous and ganglionar nodules, ultimately proving to be sarcoidosis. The clinical picture is complicated by a hepatic nodule, challenging the treatment course. The unveiling of a sarcoidosis in a previously HCV infected patient may not be accidental, the course of infection could be influenced by systemic disease. The therapy of chronic hepatitis $C$ in the context of sarcoidosis is very challenging and demands a careful monitoring ${ }^{(2)}$.
\end{abstract}

Keywords: sarcoidosis, hepatic cirrhosis, hepatitis $C$ virus.

\section{Rezumat}

Hepatita cronică virală C și sarcoidoza nu sunt neobișnuite, infecția cu VHC fiind o problemă globală frecventă, iar sarcoidoza o boală cunoscută în practica medicală. Există studii care susțin că infecția cu virus C crește riscul de sarcoidoză ${ }^{(1)}$.

Prezentăm cazul unei paciente în vârstă de 70 de ani cunoscută cu infecție cronică virală $C$, care dezvoltă determinări subcutante și ganglionare multiple în cadrul unei boli sistemice ce se dovedește a fi sarcoidoză cu implicare pulmonară silențioasă. Tabloul este complicat de apariția unui nodul hepatic ce a generat provocări diagnostice și terapeutice. Diagnosticul anatomopatologic infirmă etiologia malignă, sarcoidoza hepatică sau ciroză hepatică.

Apariția sarcoidozei la o pacientă cu infecție virală C poate să nu fie întâmplătoare, iar stadializarea bolii hepatice poate fi influențată de boala sistemică. Conduita terapeutică în infecția virală C la pacienții cu sarcoidoză este o provocare pentru clinician și implică o monitorizare atentă(2).

Cuvinte cheie: sarcoidoză, ciroză hepatica, hepatită cronică virală C. 


\section{INTERNAL}

\section{Clinical cases}

\section{Introduction}

The name of sarcoidosis dates back to 1899, when Caesar Boeck histopathologically described the cutaneous nodules in a patient suffering from this disease, although the trigger mechanism of this illness is not known $^{(1)}$. It appears that sarcoid granulomas would result from a hypersensitivity reaction in response to an extrinsic or intrinsic antigen in genetically susceptible individuals ${ }^{(3)}$. The main feature of sarcoidosis is the accumulation of granulomas in tissues, with dimensions ranging from 50 to $300 \mathrm{~mm}^{(4)}$, any organ being affected.

Sarcoidosis affects women predominantly, and two peaks occurring between 25 and 40 years old and after 50 years of age respectively are described. This is responsible for $12-30 \%$ of cases of liver granulomas $^{(4)}$.

The prevalence of sarcoidosis among patients with hepatitis $C$ virus infection is 0.1 $0.2 \%{ }^{(2)}$ and there are studies ${ }^{(6)}$ claiming that hepatitis $C$ virus infection increases the risk of sarcoidosis ${ }^{(1)}$.

\section{Case presentation}

A 70 year-old female patient was admitted to the hospital for a 14 day cough, multi-facial and cervical round to oval subcutaneous formations, $14 \mathrm{~kg}$ weight loss over the last 5 months. The patient's medical history consisted of chronic hepatitis $C$ virus infection, which was discontinued two years ago, hypothyroidism under a one-year hormone replacement therapy, elevated blood glucose values five months ago and L4L5 disc herniation discarded at the MRI (Magnetic resonance imaging) exam two months ago for which corticotherapy was administered during hospitalization. The initial cervical formations started insidious 10 months ago, followed after 3 months by an episode of acute respiratory failure, being hospitalized in the department of otorhinolaryngology with the diagnosis of acute laryngotracheitis. These were ultrasound evaluated and labelled as bilateral lateral cervical adenopathies with benign aspect.

The CT scan of the neck and thorax segments performed at the time (Figure 1, 3, 7) excluded expansive pharyngeal-laryngeal formations, revealed inferior bilateral subpleural pulmonary fibrosis infiltrate, a few bilateral pulmonary fibrotic micronodules, small submandibular adenopathies and infracentimetric cervical bilateral lymph nodes, left supraclavicular, mediastinal adenopathies up to max. $15 \mathrm{~mm}$ in diameter and has detected a nodular hepatic injury that is not sufficient for characterization on the acquisition.

Steroidal anti-inflammatory therapy 


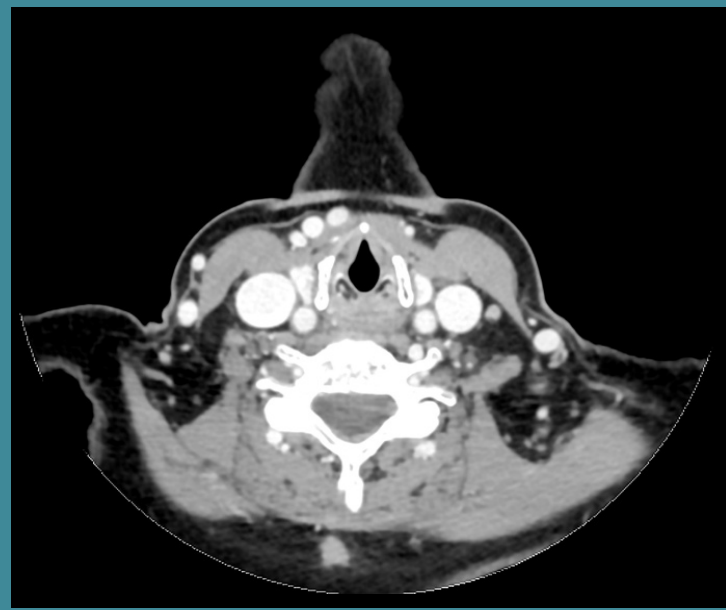

Figure 1. Subcutaneous cervical posterior node

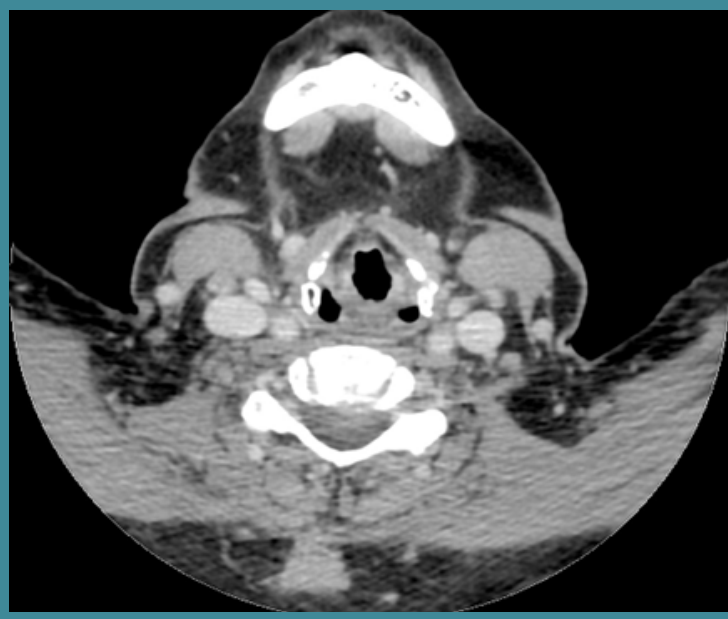

Figure 2. Subcutaneous progressive cervical posterior node

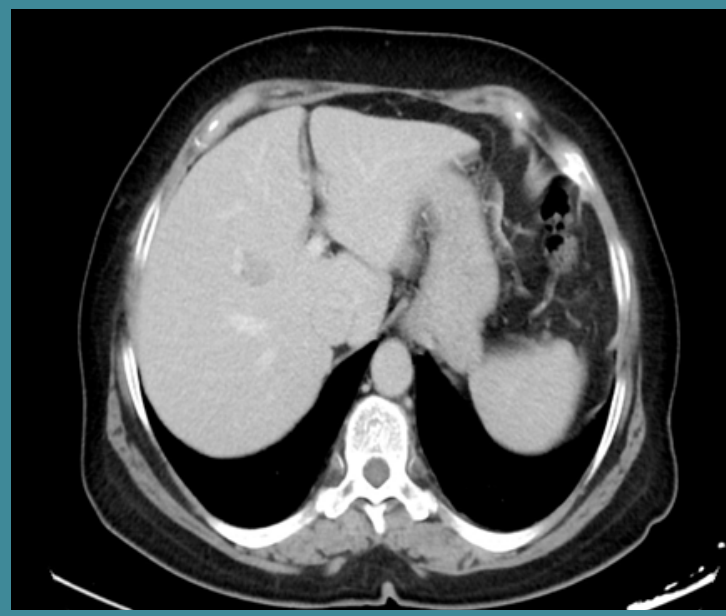

Figure 3. Liver node

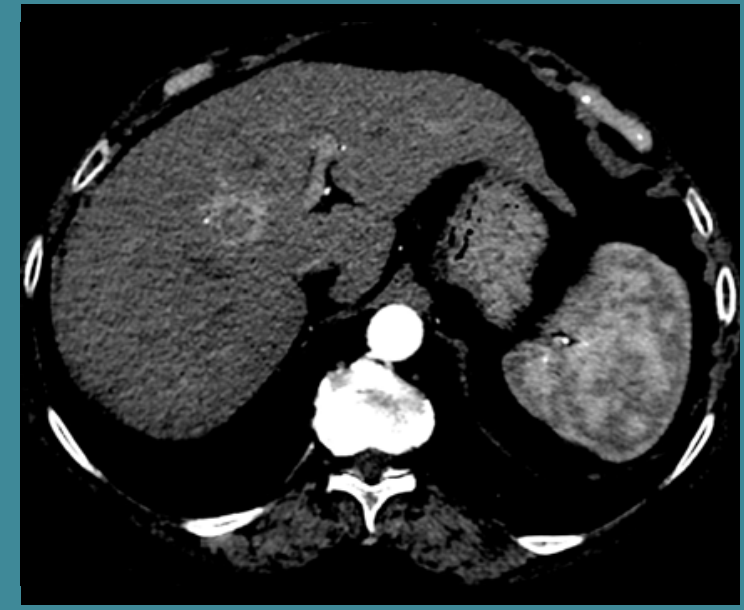

Figure 4. Hepatic artery lymph node

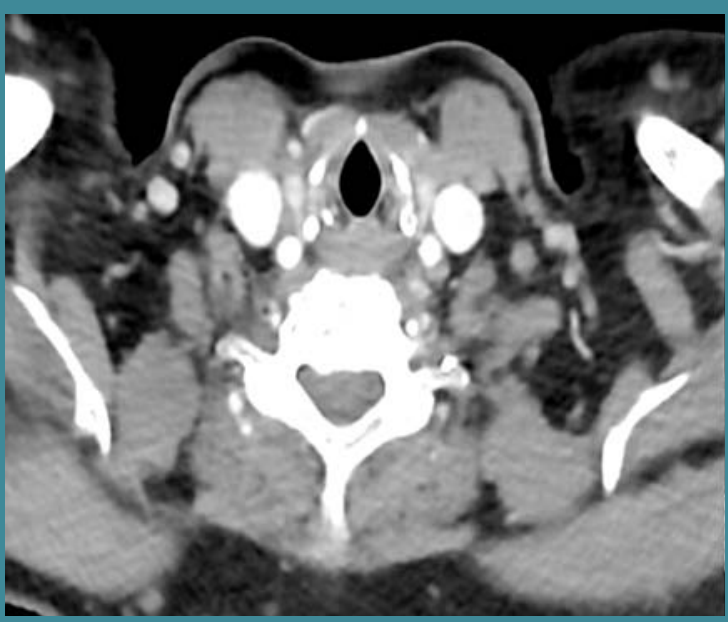

Figure 5. Subcutaneous nodule in masseteric space

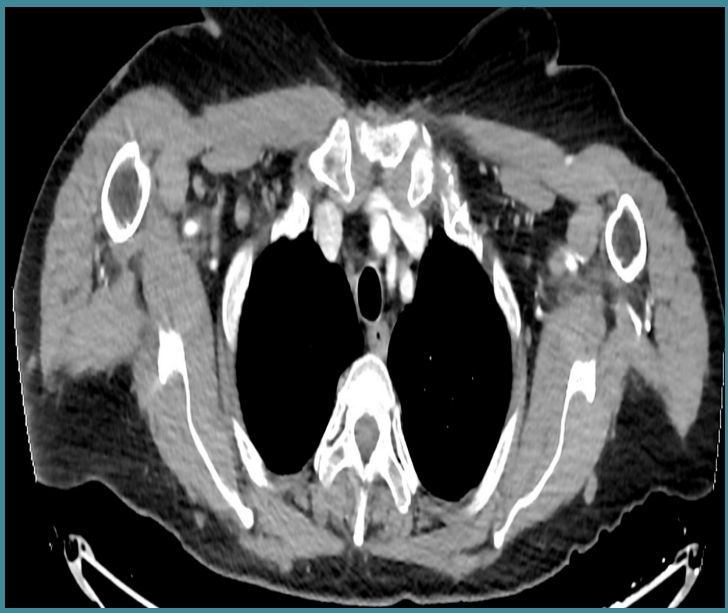

Figure 6. Subcutaneous nodules in the posterior thoracic wall 


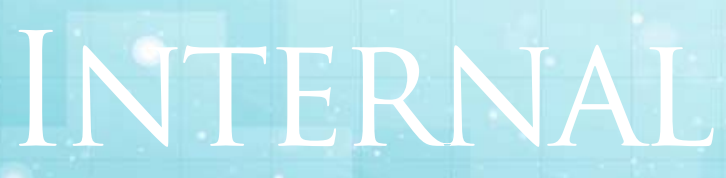

Clinical cases

(dexamethasone) was administered during hospitalization with amendment of dyspnoea and repeated antibiotic treatment. However, the patient describes the increasing number and size of the formations at that time.

In terms of liver pathology, the time and mode of hepatitis $C$ virus infection remains unknown. Viral markers were dosed as elevated aminotransferases were detected in screening assays performed prior to an ophthalmic intervention.

The abdominal ultrasounds performed did not reveal space replacing liver formations. Abdominopelvic MRI was recommended after revealing hepatocellular nodular lesions from the CT examination, which was not performed until this current visit.

The physical examination at admission identified an overweight patient, in good overall condition, afebrile, with confirmed lateral cervical retroauricular adenopathies of various dimensions, the most extended being $0.5 \mathrm{~cm} / 1 \mathrm{~cm}$, mobile to the deep planes, painless and multiple subcutaneous round to oval determinations (frontal, right orbital fossa, preauricular), of increased consistency, painless spontaneously or on palpation, with no overlying skin changes.

Without pathological changes at clinical examination of the lungs, rhythmic heart sounds, TA $=130 / 80 \mathrm{mmHg}, \mathrm{AV} 80 \mathrm{bpm}$, the rest is within normal range. Biologically, lymphopenia is identified: $16,6 \%(20-35 \%)$, thrombocytopenia: $108 \times 10^{3}\left(150-350 \times 10^{3}\right)$, AST: $105 \mathrm{U} / \mathrm{L}$ (0-37 U/L), ALP: $78 \mathrm{U} / \mathrm{L}(0-40$ $\mathrm{U} / \mathrm{L})$, serum calcium within normal range, total protein in the lower limit of normal, hypergammaglobulinemia: 19,87\% (1019.1\%), CRP: $0,701 \mathrm{mg} / \mathrm{dL}(<0,5 \mathrm{mg} / \mathrm{dL})$, ESR: $26 \mathrm{~mm} / \mathrm{h}$ (5-15 mm/h).

The abdominal ultrasound detects signs of portal hypertension, without confirming the presence of hepatocellular nodular lesions that were described at the previous CT examination. The thoracic abdominal pelvic CT scan revealed multiple adenopathies in progression compared to previous supraand subdiaphragmatic examination, multiple soft-tissue progressive nodular lesions, the most extended located upper dorsal, multiple centrilobular micronodules, massively disseminated bilaterally on pulmonary level, splenomegaly $142 \mathrm{~mm}$ which advocates for the benign etiology of the hepatic formation with a size of 13 $\mathrm{mm} / 14 \mathrm{~mm}$ (Figure 2, 4, 5, 6, 8, 9, 10, 11).

Biopsy was taken from the lateral cervical lymph nodes - three segments. The lymphoid population was predominantly composed of small lymphocytes, with round nuclei, along with rare large lymphocytes, nucleated, multiple disrupted histiocytes or forming granulomatous aggregates in interstitium, some with multinucleated giant cell, without necrosis, in the absence of acid-alcohol resistant bacilli. 

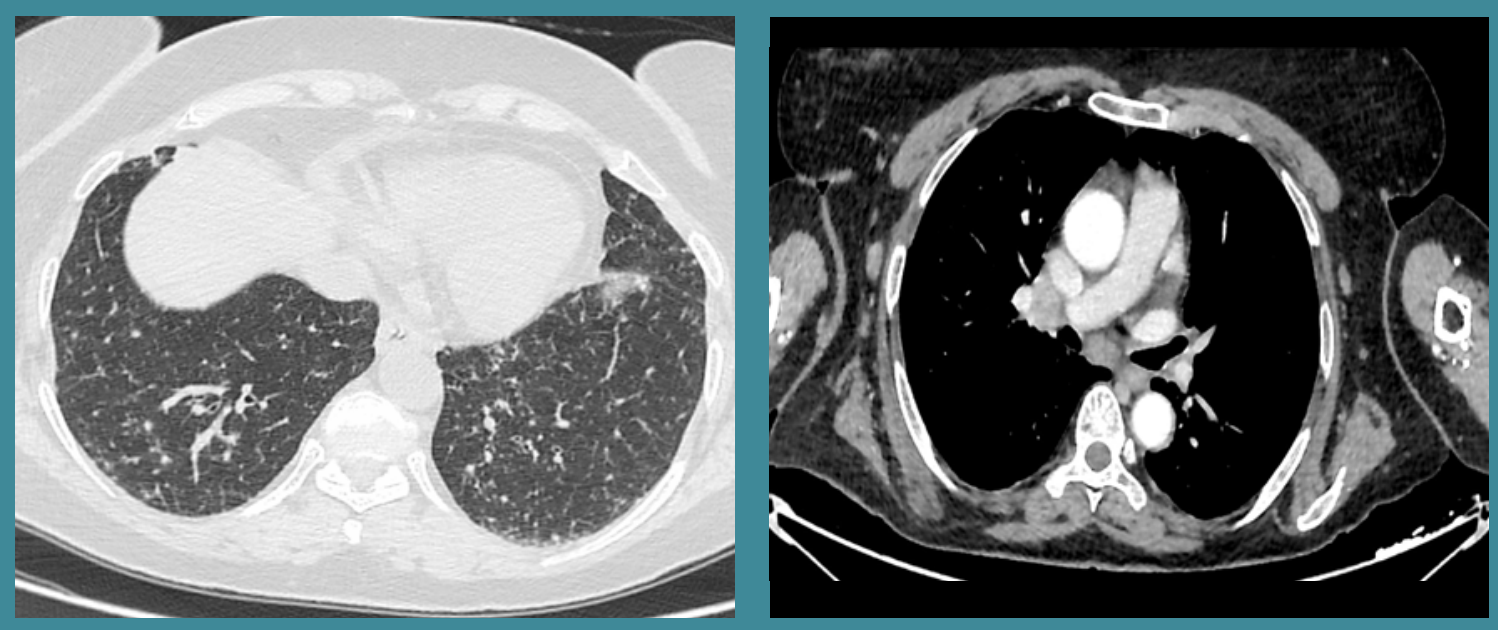

Figure 7. Pulmonary micronodules

Figure 10. Mediastinal and hilar right adenopathy
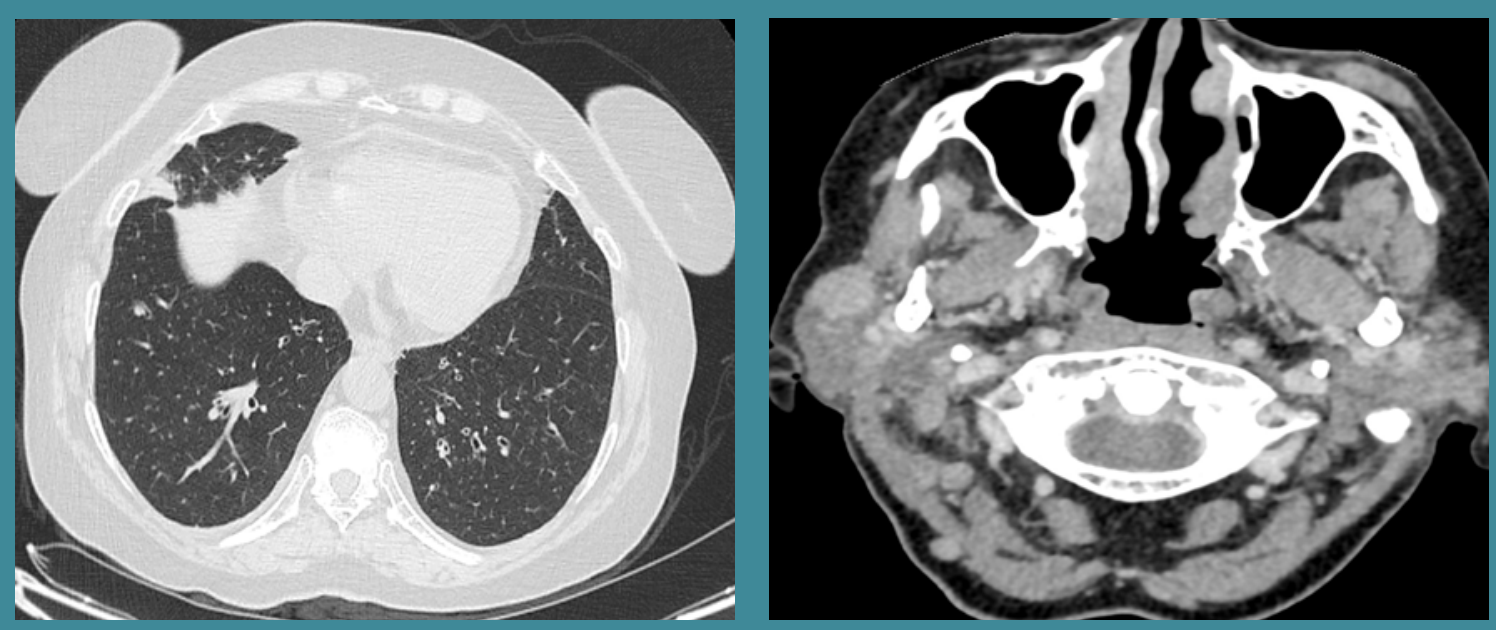

Figure 8. Reduction of pulmonary basal micronodules

Figure 11. Parotid nodules

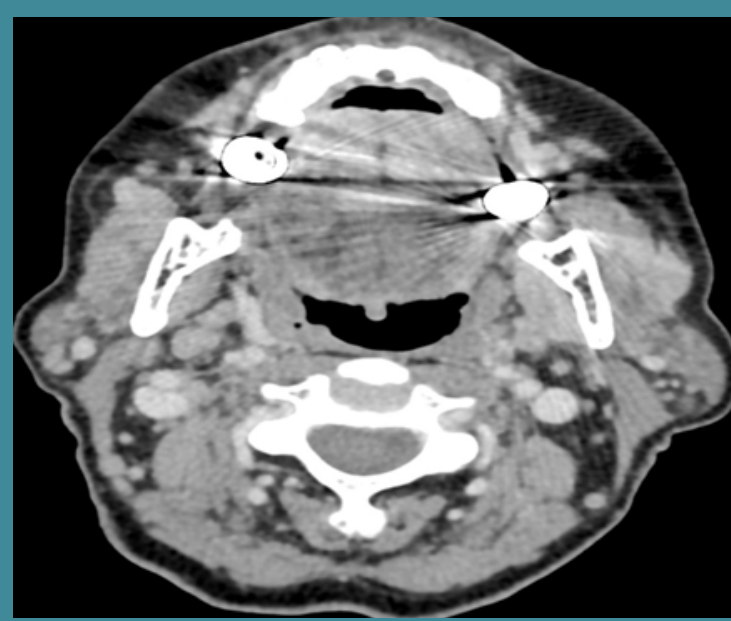

Figure 9. Cervical adenopathy 


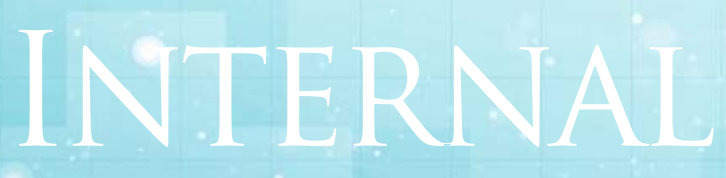

Clinical cases

The conclusion was granulomatous inflammation with uncertain etiology, possible sarcoid-like, without tumour aspect (Figure 12, 13, 14, 15). It should be mentioned that the extracted fragment was examined in two different centers with the same result.

Under these conditions, angiotensin converting enzyme (ACE) was dosed, the increased titre of $130 \mathrm{U} / \mathrm{L}$ (N12-68U/L) representing the last element to complete the diagnosis of sarcoidosis.

Meanwhile, abdominal-pelvic MRI has been performed which describes the hepatocellular nodule from segment VIII of the liver with restriction of diffusion that advocates hepatocellular proliferation, with uncharacteristic gadolinophilia, with the minimal increase in size compared to the previous CT imaging exploration seven months ago, this time measuring $22 \mathrm{~mm} / 17$ $\mathrm{mm}$ and recommends clinical-imaging monitoring of the liver formation. Also short axis lymph nodes are described with up to 10 $\mathrm{mm}$ diaphragmatic right anterior, in the hepatic pedicle, right paraceliac, in the right renal hilum and on the lumbar-aortic axis, the most extended being 12/10 mm inter-aorticocave under renal hilum. These do not show necrosis or tendency to confluence, being labelled as inflammatory non-specific.

Dosing of viraemia (ARN VHC) was recommended and corticotherapy was initiated. After two months of treatment the patient performed viraemia - 9.060.000 UI/mL $(\mathrm{N}<15 \mathrm{UI} / \mathrm{mL}$ )/6,96log UI/mL ( $\mathrm{N}$ undetectable), at which point the cortisone dose was reduced until it was discontinued, totaling three months of corticotherapy. It is worth mentioning the almost complete disappearance, shortly after the initiation of cortisone therapy, of the lymph node and subcutaneous determinations, with only one remaining lesion preauricular right.

The evolution was followed by corticotherapy complications, various infections, hypertension, infiltration of the skin, cushingoid facies, buffalo hump, sweating, of which the most important was middle lobe pneumonia (Figure 16, 17) which required hospitalization. During the hospitalization for pneumonia the CT exam was repeated, which compared with the previous examination revealed a decrease in the number of intrathoracic adenopathies, described rare micronodules, most of them fibrous, randomly distributed bilaterally across the lung, maximum $4 \mathrm{~mm}$ posterior segment of upper right lobe, slightly fibrous infiltration, posterior-basal bilateral and which this time advocates for the malignant etiology of the liver tumour. The alpha value of the fetoprotein was found within the normal range of $5.82 \mathrm{ng} / \mathrm{mL}(\mathrm{N}<7 \mathrm{ng} / \mathrm{mL})$.

After the resolution of the pulmonary infection a laparotomy was performed, with biopsy of 


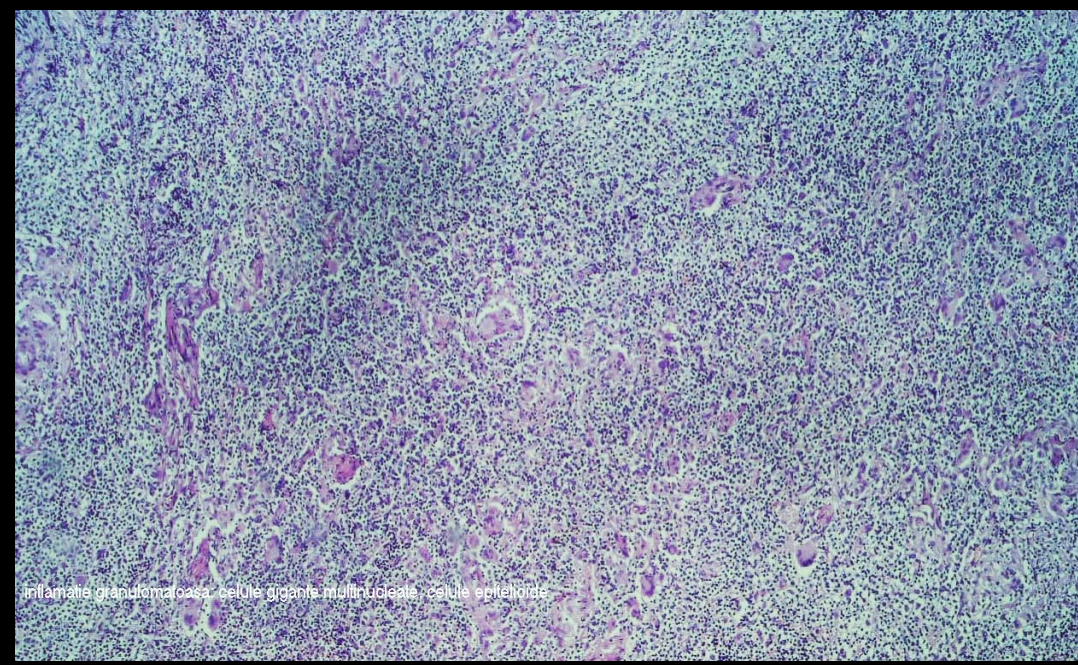

Figure 12.

Granulomatous

inflammation,

multinucleated giant

cell, epithelioid cells

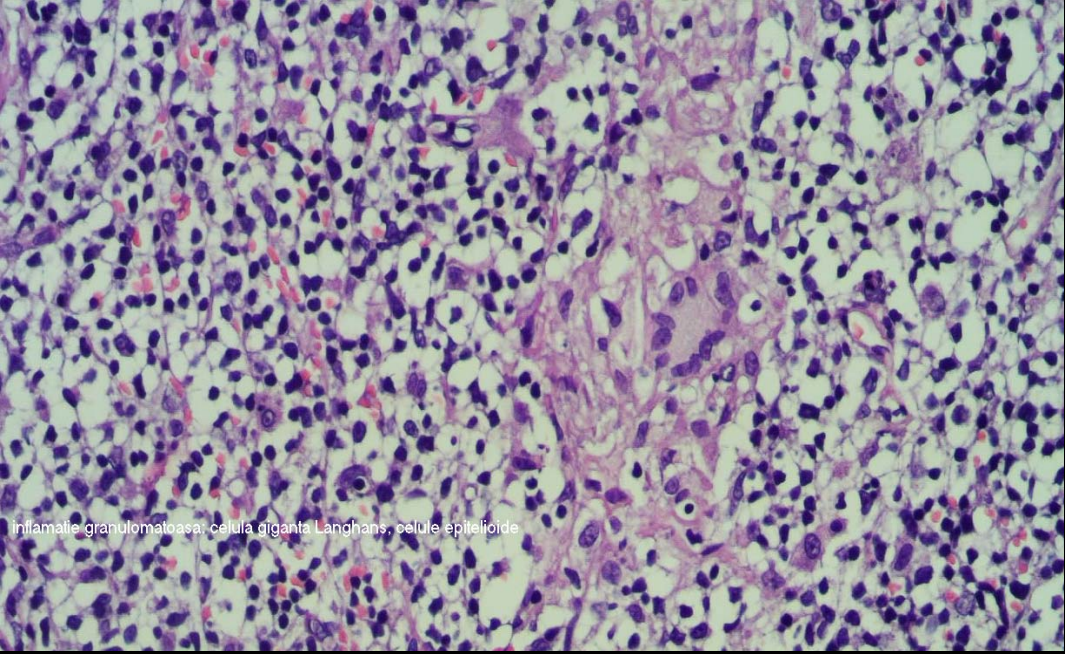

\section{Figure 13.}

Granulomatous

\section{inflammation,}

giant Langhans

cell, epithelioid

cells

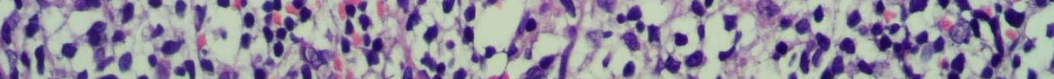

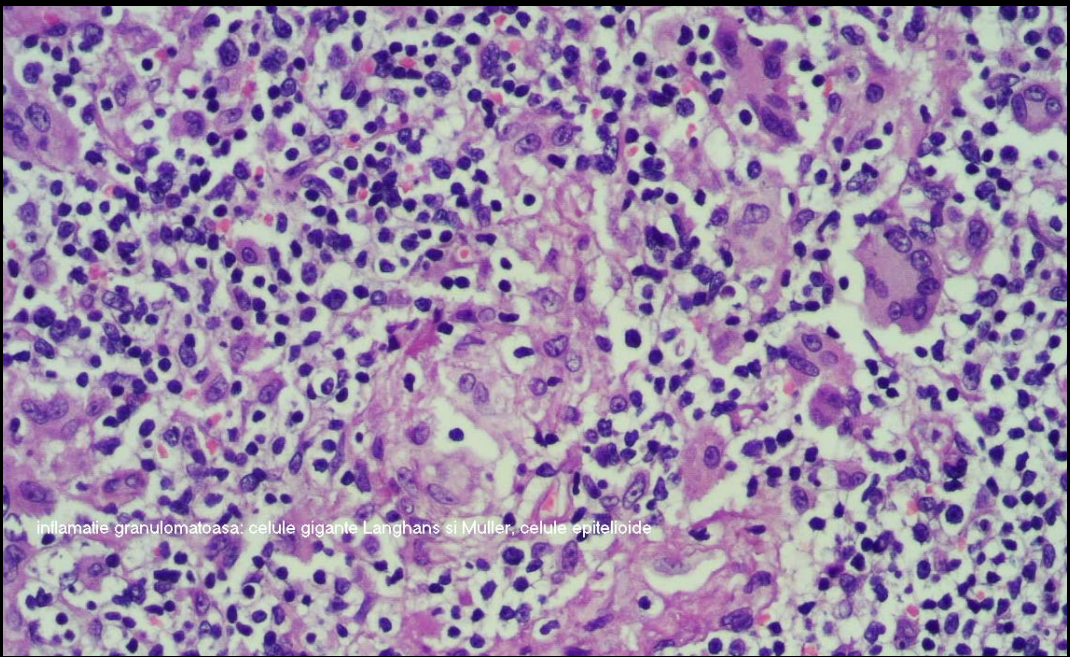

Figure 14.

Granulomatous

inflammation, giant

Muller and

Langhans cells,

epithelioid cells 


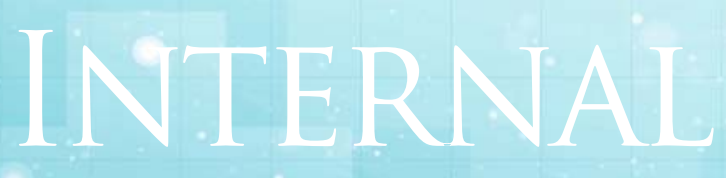

Clinical cases

the hepatic tumour formation and its thermal necrosis. The histopathological examination has infirmed the malignant etiology and revealed moderate portal lymphoplasmacytic infiltrate in all portions of the portal (score 3) with prominent follicles, lesions of interface hepatitis (score 3) and important lobular inflammatory infiltrates (score 3), macrovacuolar focal steatosis, hydropic degeneration, fibrosis in $\mathrm{F} 2$ reactive canalicular proliferation site, the anatomopathological diagnosis being severe chronic hepatitis (score F2). Two months after cessation of corticotherapy, the patient was reevaluated and recurrence of tissue determinations at the facial level was identified, in a lower number than at the onset, without causing any symptoms.

A clinical-paraclinical balance was performed, spirometry, cardiac ultrasound, abdominal ultrasound, laboratory tests - without any signs of heart disease, without further modifications, except AFP, the value of which was slightly increased this time 19.6 ( $N<7$ $\mathrm{ng} / \mathrm{mL}$ ). The patient was directed to the nearest university center to determine the opportunity for antiviral therapy. A new cortisone cure was delayed.

\section{Discussion}

The case is special in terms of diagnostic challenge, coexistence of the two diseases: hepatitis $C$ virus infection and sarcoidosis, the evolution, the difficulty of therapeutic decisions and the sequence of steps to follow. The two diseases are not uncommon. HCV infection is a common global problem, and sarcoidosis is a known disease in medical practice. The form of presentation was atypical, dominated by lymph node and subcutaneous determination, in the absence of dyspnoea. The clinical picture had been modified by short-term corticotherapy administration during the two previous hospitalizations, first in the ENT section and second in Rheumatology section.

Extrapulmonary affection is common and can affect any organ in sarcoidosis, but the isolated extrapulmonary affection is rare, less than $10 \%$ of cases are described in the literature $^{(7)}$.

Pulmonary manifestations were rough, visible only at CT examination. Thoracic radiography, which in $90 \%$ of cases of sarcoidosis is abnormal, showing lymphadenopathy and/or fibrosis $^{(5)}$, in this case it did not raise such suspicion.

The first diagnostic assumption was lymphoma, but it was infirmed by the histopathological examination. Later, after sufficient arguments have been acquired for the diagnosis of sarcoidosis-biopsy correlated with the clinical and imaging exam, ACE value - potential therapeutic options have been considered. 


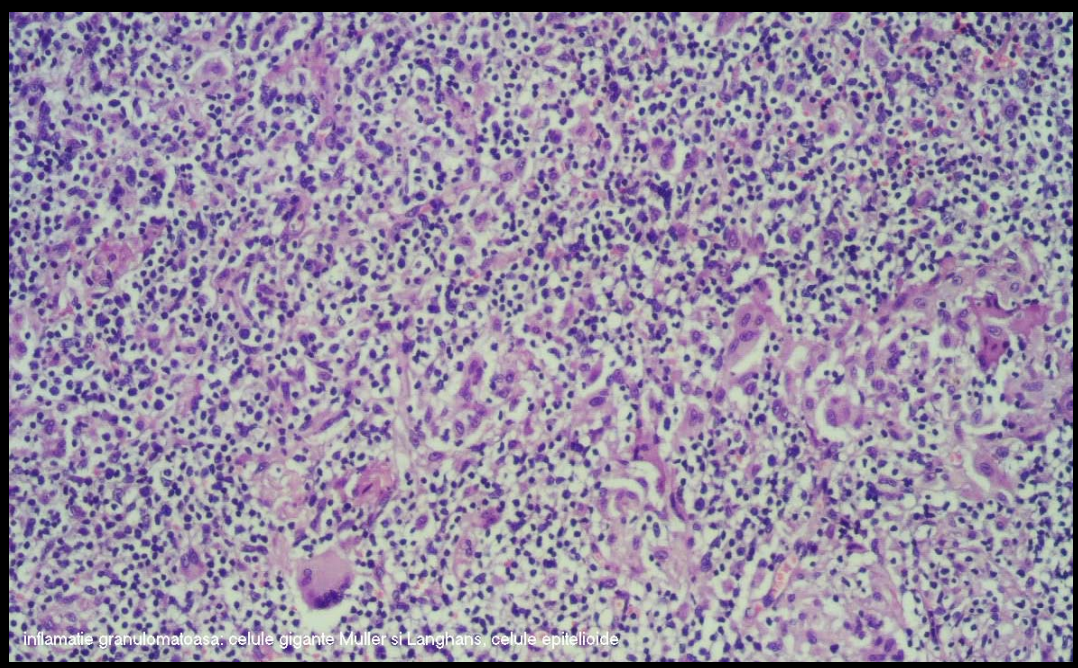

Figure 15.

Granulomatous

inflammation, giant

Muller and Langhans

cells, epithelioid cells

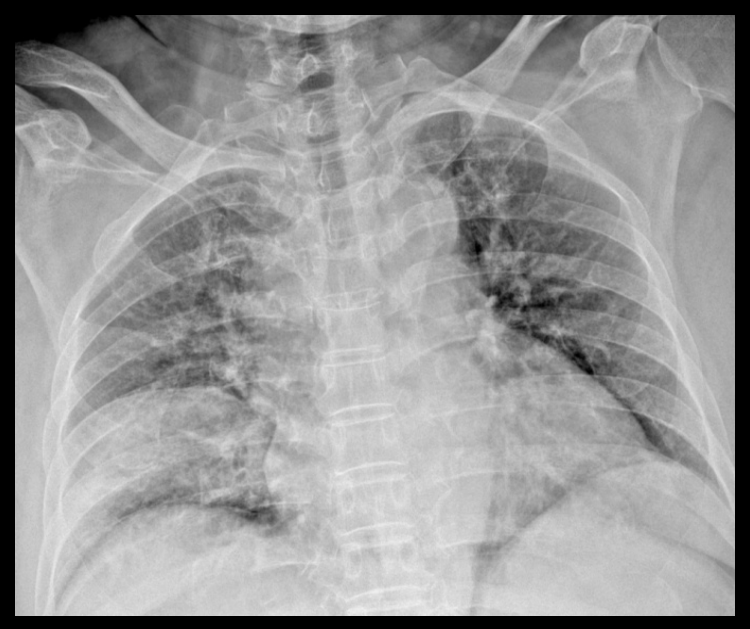

Figure 16. Middle lobe pneumonia

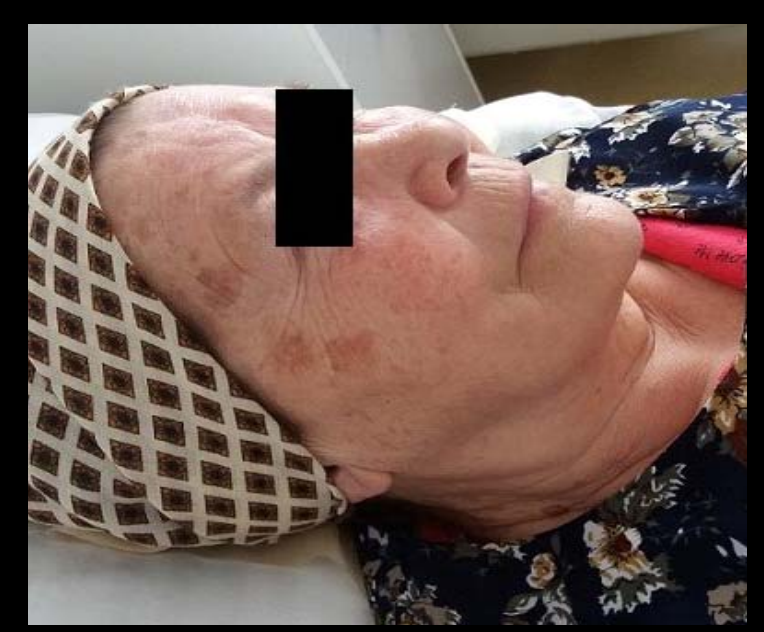

Figure 18. Subcutaneous left frontal determination

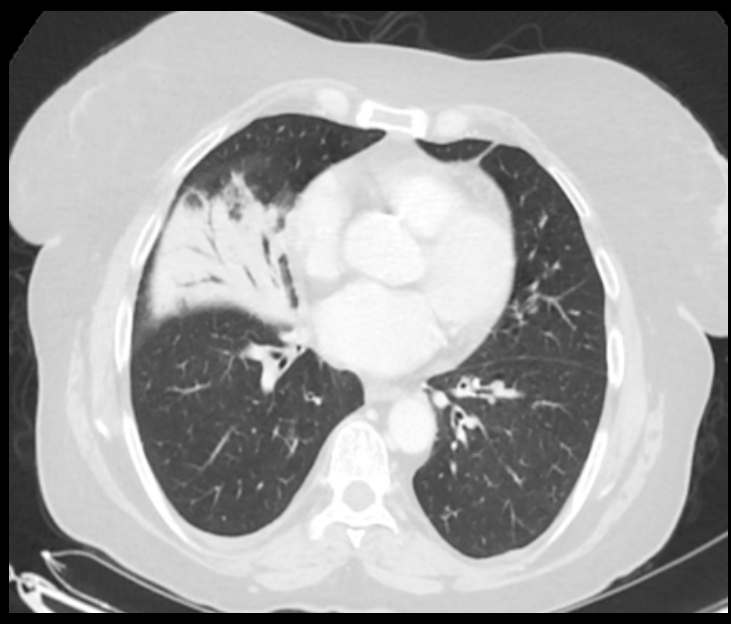

Figure 17. Middle lobe pneumonia 
Positive diagnosis in sarcoidosis is not strictly histopathological, but it is based on the correlation of clinical, imagistic and histopathological data after excluding other granulomatous disorders. It constitutes a positive argument ${ }^{1}$ when the recorded value is twice as high as the upper limit of normal ${ }^{5}$, along with the other characteristics.

The exception is Löfgren's syndrome, where the diagnosis is based on the triad of arthritis, erythema nodosum and bilateral hilar lymphadenopathy without the need for biopsy. ${ }^{1}$

There is a test with greater sensitivity and specificity than the Kveim-Siltzbach angiotensin converting test. It involves injecting a spleen fragment from a patient known for sarcoidosis under the skin of a patient suspected of having the same disease. If a non-caseating granuloma develops at 4-6 weeks, the test is considered positive. However, it is not recommended because the material is difficult to obtain and the risk of infection is high ${ }^{(8)}$.

Lymphopenia is justified in sarcoidosis: it decreases the number of circulating $T$ helper lymphocytes, as they are cantonized into various tissues, proliferating and leading to granulomatous inflammation ${ }^{(8)}$. While skin sarcoidosis is common, subcutaneous sarcoidosis is rare and occurs as a distortion of the skin landscape without altering the adjacent skin $^{(10)}$ (Figure 18)
There are also reported cases of sarcoidosis developed in recent or old scars after minimal skin trauma, such as tattoos, venous puncture, herpes zoster infection. An atypical case was described in Geneva by Dulguerov et al. - subcutaneous sarcoidosis after rhinoplasty, basically a case of sarcoidosis on a scar, but not cutaneous ${ }^{(10)}$.

Darrier and Roussy described subcutaneous sarcoidosis in 1904, detailed by Vainsencher and Winkelmann in 1984: epidermis and dermis are not involved, while the hypoderm is the one affected, the development of granulomas taking place here ${ }^{(12,13)}$. Subcutaneous sarcoidosis affects predominantly the limbs and less often the face and neck ${ }^{(14)}$, as it was in this case.

The differential diagnosis of systemic disease was performed between the solid tumour with secondary glandular determinations, lymphoma, tuberculosis and sarcoidosis. The difference between chronic hepatitis and cirrhosis was considered and the third discussion involved the diagnosis of the liver nodule: hepatocarcinoma, hemangioma, hepatocellular adenoma, focal nodular hyperplasia, hepatic sarcoidosis, regenerative nodule in cirrhosis.

From the therapeutic point of view, methotrexate was excluded in the context of the liver disease. The most indicated treatment was corticotherapy, the main limitation being the adverse effect on 
hepatitis $\mathrm{C}$ virus activity. Administration of corticotherapy to patients with HCV infection favors the progression of viral disease through the upregulation mechanism of cellular entry factors: occlusion and type B scavenger type I receptor ${ }^{(15)}$.

This is important in this patient who already has a suspected hepatic tumour. Subcutaneous and ganglionic determinations that are increasingly significant, most notably those at the level of the right orbital obstruction of sight, the presence of pulmonary damage have made corticotherapy necessary at least on short term.

Pulmonary sarcoidosis in pulmonary fibrosis stage increases morbidity and mortality due to background disease, sequelae of pulmonary disease, pulmonary hypertension and infections ${ }^{(16)}$. At that time it was recommended to measure the viraemia, and the imaging arguments for the benign etiology of the formation were considered.

The effects of sarcoidosis treatment were favourable with signs of reduced disease activity: close to total disappearance of subcutaneous and lymph node determinations - one single lesion- with diminishing number and diameters of systemic adenopathies, reduction of lung micronodules. Drug side effects were noticed, the most important being middle lobe pneumonia with acute respiratory failure.

Another important aspect is the staging of the degree of hepatic damage in the context of hepatitis $C$ virus. There were no clear signs of cirrhosis of the liver. Splenomegaly was detected, but with a portal vein at the upper limit of normal (12 $\mathrm{mm}$ ) and the absence of esophageal varices in the upper endoscopic examination. Biologically, hypergammaglobulinemia was found, but the total protein was at the lower limit of normal, and normal albuminemia.

Splenomegaly can be interpreted in the context of sarcoidosis, all the more so as it has been reduced under corticotherapy (the decrease in the longitudinal diameter of 147 $\mathrm{mm}$ to $116.5 \mathrm{~mm}$ ), as well as hypergammaglobulinemia, a feature described in sarcoidosis. Ultrasound elastography would have been useful for diagnostic orientation, but the only revealing investigation was hepatic biopsy that the context constrained patient had done. Thus, malignancy, liver sarcoidosis and even cirrhosis were excluded, the liver disease was labelled as severe chronic hepatitis F2.

Hepatic involvement with pulmonary hypertension, varicose hemorrhage, hepatopulmonary syndrome and cirrhosis leading to liver failure exists, but is described in only $1 \%$ of cases of sarcoidosis ${ }^{(1)}$. In general, hepatic impairment is silent, in $5-15 \%$ cases of hepatic or splenic lesions being described in the CT examination ${ }^{(1)}$.

There is a retrospective study over a considerable time period of 37 years-345 cases of sarcoidosis- $6 \%$ of those with hepatic impairment. Only four patients had liver cirrhosis, two of them upon diagnosis, and the other two developed the disease later ${ }^{(17)}$. Liver involvement in sarcoidosis is usually asymptomatic, therefore it is clinically underdiagnosed and frequently found in late stages of cirrhosis and liver failure. Frequent increases in GGT (gamma glutamyl transpeptidase) and alkaline phosphatase levels are found. ${ }^{17}$

Hepatic impairment was found in $70 \%$ of autopsy patients in a Japanese study ${ }^{(18)}$.

On a clinical-paraclinical review performed a month after the excision of the hepatic formation, restraint from the corticotherapy was decided, at least until obtaining the 
sustained antiviral response, considering also the fact that sarcoidosis signs were not severe in this case, the clinical and biologic picture, respiratory functional tests and chest X-ray (Figure 12) representing strong arguments in this sense.

A new issue occurs at this point, when the patient, according to the biopsy result, is not a good candidate for direct antiviral therapy, and to whom interpheron treatment would be indicated considering the hepatic impairment. The effects of the interpheron treatment are not fully known in patients with sarcoidosis. In $75 \%$ of the chronic $\mathrm{C}$ hepatitis and sarcoidosis the treatment with interpheron alfa and ribavirin have preceded the occurrence of sarcoidosis, making room for causality suspicion, however, cases of sarcoidosis and untreated hepatitis C infection, which means that it is not excluded ${ }^{6}$ that the viral infection itself leads to sarcoidosis development. ${ }^{2}$

According to some authors ${ }^{1}$ it is likely that in fact the treatment with interpheron alfa, through the rise of TNF gamma and IL2 stimulates the formation of granuloma. In chronic $\mathrm{C}$ hepatitis, the possibility of hepatic granuloma is described $(0,8-9,5 \%$ of positive biopsies for granuloma before the initiation of interpheron treatment $)^{(2,19)}$.

These aspects indicate the possibility of a similar immune pathogenic mechanism in both affections. The disorder of the cytokine and chemokine network in patients with hepatitis $C$ viral infection, amid a predisposition towards it, can lead to the formation of granuloma through the release of the mediators and the monocyte activation. Vadin et $\mathrm{al}^{(2)}$ described a case of pulmonary and cutaneous sarcoidosis (nodular erythema) in a patient with untreated hepatitis $C$ viral infection (diagnosis confirmed by hepatic and pulmonary biopsy). After one month of chorticotherapy, the secondary symptomatology remitted. Later on, hepatic sarcoidosis was observed - noncaseating granuloma on biopsy and suggestive imagery for persistent pulmonary disorder. Antiviral treatment with peginterpheron $\alpha-2 a$ and ribavirin was initiated, with good result, obtaining a sustained viral response. During five months of follow up, no specific sarcoidosis signs have been noted in the absence of chorticotherapy. The majority of the patients diagnosed with sarcoidosis go into remission, however in approximately $25 \%$ of the cases, the disease has a progressive, chronic evolution ${ }^{(20)}$.

\section{The peculiarity of the case}

The mode of presentation, with the predominant subcutaneous and ganglionar determination and not pulmonary, normal thoracic $X$-ray initially, the association of 
chronic hepatitis C virus infection with sarcoidosis and hepatic nodule, predominant subcutaneous impairment of the face and neck and not of limbs represent the peculiarities of this case.

\section{Conclusions}

- The occurrence of sarcoidosis in a patient with hepatitis $C$ infection may not be random.

- Sarcoidosis in a patient with chronic C viral infection can make the staging of the hepatic disease difficult.

- The therapeutic approach in C viral infection in patients with sarcoidosis is a challenge for the clinician and implies a careful monitoring ${ }^{(2)}$.

\section{References}

1. Michael C. Iannuzzi, M.D., Benjamin A. Rybicki, Ph.D., and Alvin S. Teirstein, M.D., "Sarcoidosis", The New England Journal of Medicine,2007;357:2153-65.

2. Vadim Brjalin, Riina Salupere, Valentina Tefanova, si colab., "Sarcoidosis and chronic hepatitis C: A case report ", World J Gastroenterol, 2012; 18(40): 5816-5820. 3. Mahony J, Helms SE, Brodell RT, "The sarcoidal granuloma: A unifying hypothesis for an enigmatic response", Clin Dermatol., 2014;32(5):654-9.

4. MarcyCoash, FaripourForouhar, Catherine H.Wu, George Y.Wu, "Granulomatous liver diseases: A review", Journal of the Formosan Medical Association, 2012, 111, 3-13.

5. Hilario Nunes, Diane Bouvry, Paul Soler and Dominique Valeyre, "Sarcoidosis", Orphanet Journal of Rare Diseases, 2007, 2:46.

6. Bonnet F, Morlat P, Dubuc J si colab., "Sarcoidosisassociated hepatitis C virus infection", Dig Dis Sci, 2002; 47: 794-796

7. Giovinale M1, Fonnesu C, Soriano A si colab., " Atypical sarcoidosis: case reports and review of the literature:, Eur Rev Med Pharmacol Sci., 2009 Mar;13 Suppl 1:37-44.

8. Kveim-Test, Wikipedia, https://en.wikipedia. org/ wiki/Kveim_test.

9. Haider Mosea, James Gotto, Zubair Khan," Diagnostic and therapeutic challenges of hepatic sarcoidosis", BMJ Case Reports 2011; doi:10.1136.

10. Nicolas Dulguerov, Lenka Vankatova, Basile Nicolas,

" CASE REPORT Subcutaneous sarcoidosis in a rhinoplasty scar", BMJ Case Rep Published online, 2015 doi:10.1136.

11. B. W. Hancock, "Cutaneous Sarcoidosis in Blood Donation Venepuncture Sites", British Medicaljournal, 1972, 4, 706-708.

12. Darier J, Roussy G., " Un cas de tumeurs bénignes multiples: Sarcoïdes sous-cutanées ou tuberculides nodulaires hypodermiques", Ann Dermatol Syphiligr 1904;5:1449.

13. Vainsencher $D$, Winkelmann RK., "Subcutaneous sarcoidosis", Arch Dermatol 1984;120:102831.

14. Ahmedl, Harshad SR., "Subcutaneous sarcoidosis: is it a speci?c subset of cutaneous sarcoidosis frequently associated with systemic disease?", J Am Acad Dermatol, 2006;54:5560.

15. Successful treatment of systemic de novo sarcoidosis with cyclosporine discontinuation and provision of rapamune after liver transplantation Transplant International a 2011 European Society for Organ Transplantation 24 (2011) e69e70.

16. Catherine A. Bonham, Mary E. Strek, and Karen C. Patterson, "From granuloma to fibrosis: sarcoidosis associated pulmonary fibrosis", Curr Opin Pulm Med. 2016 Sep; 22(5): 484491.

17. Patompong Ungprasert, Cynthia S. Crowson, Douglas A. Simonetto and Eric L. Matteson, "Clinical Characteristics and Outcome of Hepatic Sarcoidosis: A Population-Based Study 19762013", Am J Gastroenterol . 2017 October; 112(10): 15561563.

18. Iwai K, Oka H., " Sarcoidosis: report of ten autopsy cases in Japan", Am Rev Respir Dis. 1964; 90:61222.

19. Ozaras $R$, Tahan V, Mert A si colab., "The prevalence of hepatic granulomas in chronic hepatitis", C. J Clin Gastroenterol, 2004; 38: 449-452.

20. Robert $P$ Baughman, "Review Pulmonary hypertension associated with sarcoidosis", Arthritis Research \& Therapy, 2007, 9(Supp/ 2):S8. 